\title{
Trade Liberalization and Technical Efficiency in the Indonesian Chemicals Industry
}

\author{
Bernadetta Dwi Suatmi ${ }^{1}$ \\ Harry Bloch ${ }^{2}$ \\ Ruhul Salim*2 \\ ${ }^{1}$ Kwik Kian Gie School of Business, Jl. Yos Sudarso Kav. 87, Sunter, Jakarta Utara, DKI Jakarta \\ Indonesia, 14350 \\ ${ }^{2}$ School of Economics and Finance, Curtin Business School, Curtin University, Australia
}

${ }^{*}$ Corresponding address: School of Economics \& Finance, Curtin Business School, Curtin University, Perth, WA 6845. Phone: +61 89266 4577, Fax: +61 89266 3026, E-mail: Ruhul.Salim@ cbs.curtin.edu.au 


\title{
Trade Reform and Technical Efficiency in the Indonesian Chemicals Industry
}

\begin{abstract}
This paper examines the impact of trade reform on technical efficiency on the Indonesian chemicals industry using firm-level panel data. The effects of trade reform on technical efficiency are analysed using a stochastic frontier approach. Two variables represent trade reform in this model: effective rate of protection (ERP) and import ratio (IMP). The findings of the present study suggest that both trade reform variables have significant effects on technical efficiency. The coefficient of ERP has a positive sign and is statistically significant, which means that an increase in ERP increases the inefficiency (or decreases the technical efficiency) of firms in the chemicals industry. The coefficient of IMP is negative and statistically significant, which represents the negative impact of IMP on technical inefficiency (or positive on technical efficiency). Thus, trade reform, a reduction in ERP or an increase in IMP, has an unambiguously positive effect on technical efficiency in the Indonesian chemicals industry.
\end{abstract}

Key Words: Trade liberalization; Technical efficiency; Stochastic frontier; Panel data JEL Classification: C20, D24, D29, F13

\section{Introduction}

Over the past two decades, trade reform has been employed as a development strategy in many developing countries. In particular, trade reform is widely believed to benefit developing countries by generating improvements in technical efficiency (Handoussa et al. 1986, Tybout et al. 1991, Alam and Morrison 2000). There are four channels through which trade reform can improve technical efficiency. First, trade reform increases the greater access to imported capital goods and technological advances from leading nations (Romer 1986, Krugman 1987, Lucas 1988). Learning by domestic researchers who use and/or study these goods leads to greater technical efficiency. Second, trade reform can increase industrial productivity through the pressures of international competition (Amiti and Konings 2007, Loecker and Goldberg 2013). To compete with international producers, domestic producers must adopt newer and more efficient technologies or employ previously used technologies with less X-inefficiency to reduce cost (Nishimizu and Page 1982). Third, trade reform can increase productivity and efficiency through technical knowledge spillovers (Grossman and Helpman 1991), which may occur by means of suggestions to improve the manufacturing process from foreign buyers. Fourth, trade reform can increase technical efficiency through transferring organizational and managerial effort brought from multinational corporations as suppliers or buyers to domestic 
firms, which may include the ability to organize and integrate production across countries and the ability to establish marketing network (Corden 1974, Rodrik 1992b, Dhanani 2000).

Although the theoretical literature leaves no doubt as to trade reform's beneficial effects on improving technical efficiency, the empirical evidence is inconclusive (Pack 1988, Rodrik 1992a). Different results of earlier empirical studies may be due to different methods used in those studies and the differences in the impact of trade reform across industries. Several studies suggest that trade reform has a positive impact in increasing technical efficiency, including Gökçekuş (1995), Alam and Morrison (2000), Driffield and Kambhampati (2003), Sheikh and Ahmed (2011). By contrast, other empirical studies show that trade reform has no or little impact on technical efficiency, such as Handoussa et al. (1986), Kalirajan and Salim (1997), Salim (1999, 2009), Tybout et al. (1991), and Parameswaran (2002).

There are several empirical studies of technical efficiency in Indonesian manufacturing, including Pitt and Lee (1981), Hill and Kalirajan (1993), Margono and Sharma (2006), Ikhsan (2007), Suyanto et al. (2009), and Suyanto et al. (2012). These studies examine the determinants of technical efficiency in Indonesian manufacturing using SFA and incorporate several industry-specific and other variables that may influence firm technical efficiency. However, none of these studies specifically investigates the effects of trade reform on technical efficiency.

This study contributes to the literature in several ways. To date, there has been no systematic study of the impact of trade reform on technical efficiency in the Indonesian chemicals industry and this study is one of the first attempts to perform such a study using firm-level panel data categorised under the two-digit International Standard for Industrial Classification (ISIC). The Indonesian chemicals industry is chosen in this study. The main reason to choose this industry is the economic importance of this sector during the sample period 1981-2000 when the industry contributed an average of approximately $15 \%$ and over $11 \%$ in manufacturing output and employment, respectively.

Second, this research employs a one-stage stochastic frontier analysis (SFA) with inefficiency effects, rather than a conventional production function. The separation of inefficiency effects may shed light on the continuing debate over the effects of trade reform on technical efficiency. Third, this study focuses on the Indonesian chemicals industry only rather than on pooling data for all Indonesian manufacturing industries. Focusing on firm-level data from a specific industry can reduce heterogeneity in data, as suggested by Bartelsman and Doms (2000). 
The rest of this paper proceeds as follows: Section 2 provides an overview of trade reform and the Indonesian chemicals industry, which is followed by discussion of the model specification and estimation techniques in Section 3. Section 4 identifies the data sources. Section 5 presents the results for model selection and estimation followed by an analysis of empirical results. The summary of findings and policy implications is given in the final section.

\section{An Overview of Trade Reform and the Indonesian Chemicals Industry}

Since 1967 Indonesia has been implementing various reform policies moving between inwardlooking policies. As discussed in the literature (Hill 2000, Widodo 2008, Aswicahyono et al. 2010), there have been at least five phases of the industrial development and international trade policies in Indonesia. Indonesia has had the experience of shifting in trade regime from liberal trade to a protective one during the period of oil boom and then going back to liberal trade regime during the decline of oil price. Hit by economic crisis and pressure from international commitments with IMF, AFTA, APEC, and WTO, Indonesia then reformed its trade and industrial policy to a more open economy.

The reform package was designed to improve the efficiency of manufacturing sectors by increasing competition from domestic economy as well as from outside. The reform package included reduction in tariff levels and non-tariff barriers, relaxation of investment regulations, and reduction reliance of public enterprises. The reform also included financial reform, fiscal reform, and FDI (foreign direct investment) deregulation.

During the 1970s, due to the oil boom, Indonesia adopted inward-looking importing substitution strategy. Trade protection levels were relatively high from the 1970s up to the mid1980s (Basri 2002). Manufacturing was also highly protected by non-tariff barriers (NTB). Indonesian government involvement was carried out through state owned enterprises (SOEs) and several private companies that granted industrial licensing and import protection by government. This strategy was ended in the mid-1980s due to the decrease of oil price.

Since the mid-1980s the government changed the orientation strategy to outward-looking policies by adopting export oriented strategy. Trade protection has been reduced significantly. In 1985 tariff ceilings of $60 \%$ were introduced. The Asian economic crisis in 1997 also encouraged the government to implement more liberalized policies.

In this study, the Indonesian chemicals industry is taken as a case study in examining the impact of trade reform on technical efficiency. The chemicals industry represents about $27 \%$ of Indonesian manufacturing output and around 13\% of the manufacturing employment in 2010. Its contribution to the manufacturing value added (MVA) was the third highest of all industries 
after the foods and textiles. During 1981-2010, this industry expanded rapidly, increasing in value added by more than 340 times.

The Annual Survey of Manufacturing Industries divides this industry into six sub-sectors: industrial chemicals (ISIC 351), pharmaceutical and other chemicals (352), oil and gas refinery (353 and 354), rubber and rubber products (355), and plastic products (356). Industrial chemicals and pharmaceutical and other chemicals are important components in the chemicals industry group. These two sub-sectors represent more than $60 \%$ of the sector value added.

The trend and key indicators of the Indonesian chemicals industry during the study period are presented in Table 1 . Table 1 shows that the Indonesian chemicals industry expanded rapidly during 1981-1998, with an increase in output by eight times. Exports of the chemicals industry have varied over the period, but were less than 30\% during 1981-1998. In contrast, there was a heavy reliance on imported material, with more than $30 \%$ of total material imported for each observation in the table. ERP decreased considerably during the observation period, from $111 \%$ in 1981 to $23 \%$ in 1998.

\section{Table 1: Key Indicators of the Indonesian Chemicals Industry}

\begin{tabular}{lrrrrr}
\hline Indicators & 1981 & 1985 & 1990 & 1995 & 1998 \\
\hline & & & & & \\
Output (billion rupiah, in 1993 constant & & & & & \\
price) & 37.04 & 83.51 & 139.92 & 192.35 & 294.76 \\
Output share (\% of manufacturing) & 18.44 & 19.50 & 16.99 & 15.19 & 17.43 \\
Labour (thousands of people) & 121 & 248 & 383 & 472 & 463 \\
Labour (\% of manufacturing) & 11.97 & 14.73 & 14.39 & 11.31 & 11.23 \\
Number of establishments & 851 & 1,626 & 2,059 & 2,412 & 2,394 \\
Foreign Firm (\% of establishments) & 10.93 & 8.00 & 8.45 & 10.07 & 13.03 \\
Domestic Firm \% of establishments) & 84.02 & 86.90 & 85.28 & 85.20 & 82.25 \\
SOEs (\% of establisments) & 5.05 & 5.10 & 6.27 & 4.73 & 4.72 \\
Foreign share (\%VA) & $\mathrm{n} . \mathrm{a}$ & $\mathrm{n} . \mathrm{a}$ & 61.67 & 45.66 & 10.48 \\
Export (\% of output) & $\mathrm{n} . \mathrm{a}$ & $\mathrm{n} . \mathrm{a}$ & 17.39 & 26.00 & 9.65 \\
Imported-material (\% of total material) & 43.84 & 40.13 & 41.67 & 32.99 & 34.29 \\
ERP (\%) & 111.30 & 103.98 & 61.07 & 33.59 & 23.60 \\
\hline
\end{tabular}

Source: Authors' calculation from the Annual Survey of Large and Medium Manufacturing Industries. Foreign firms are defined as firms with any foreign ownership, domestic firms are firms those $100 \%$ owned by domestic private individual or companies, and state-owned enterprises (SOEs) are firms owned by central or district government.

\section{Model Specification and Estimation Techniques}

There are several alternative methods in measuring technical efficiency at the firm level, such as conventional cost (production) functions, data envelopment analysis (DEA), and stochastic frontier cost (production) function. Each of these methods has its advantages and disadvantages. The argument over which method is appropriate continues (Coelli et al. 2005). 
In this study, the stochastic frontier production function is applied to test the impact of trade reform on technical efficiency. ${ }^{1}$ Following Battese and Coelli (1995), the stochastic frontier approach (SFA) is used to estimate a production function and an inefficiency function simultaneously. The Battese-Coelli model is as follows:

$y_{i t}=\alpha_{0 t}+x_{i t} \beta+v_{i t}-u_{i t}$

where $y_{i t}$ is the scalar of the logarithm of output for firm $i(i=1,2, \ldots, N)$ at time $t(t=1,2$, $\ldots, T), \alpha_{0 t}$ is the production frontier intercept common to all firms in time $t, x_{i t}$ is a $(1 \mathrm{x} k)$ vector of the logarithm of inputs used by firm $i$ at time $t, \beta$ is a $(k \times 1)$ vector of unknown parameters to be estimated. The error consists of two components: $v_{i t}$ and $u_{i t}$. The $v_{i t}$ is a random error which is assumed to be iid $N\left(0, \sigma_{v}^{2}\right)$ and is distributed independently of the $u_{i t}$. The $u_{i t}$ is a technical inefficiency effect which is assumed to be independent, but not identically distributed, such that $u_{i t}$ is obtained by truncation (at zero) of the normal distribution with mean, $m_{i t}$ and variance $\sigma_{u}^{2}$, that is $u_{i t} \sim N^{+}\left(m_{i t}, \sigma_{u}^{2}\right)$.

The technical inefficiency effect, $u_{i t}$, is a function of a $(1 \times s)$ vector of exogenous variables, $z_{i t}$, and a $(s \times 1)$ vector of unknown parameters to be estimated, $\delta$. In a linear format, the technical inefficiency effect $u_{i t}$ can be written as:

$u_{i t}=z_{i t} \delta+w_{i t}$

where $w_{i t}$ is an unobservable random error and is defined by the truncation of a $N^{+}\left(0, \sigma_{w}^{2}\right)$ distribution with point of truncation at $-z_{i t} \delta$. This assumption implies that $w_{i t} \geq-z_{i t} \delta$.

The parameters of the stochastic production frontier and the technical inefficiency effects in Equations 1 and 2 are simultaneously estimated using a maximum likelihood (ML) method. The likelihood function is parameterized in terms of the variance parameters, $\sigma_{s}^{2} \equiv \sigma_{v}^{2}+\sigma_{u}^{2}$ and $\gamma \equiv \frac{\sigma_{u}^{2}}{\sigma_{u}^{2}+\sigma_{v}^{2}}$ (Battese and Coelli 1995). If $\gamma$ equals zero, the model reduces to a traditional mean response function in which $z_{i t}$ can be directly included into the production function.

A flexible translog (Transcendental Logarithmic) production frontier is chosen for the production function in Equation 1 as it is more flexible and imposes relatively fewer restrictions on the structure of production. One important change to the economic conditions during the period of observation was the economic crisis that occurred in 1997. This study takes the economic crisis into account by including a dummy for the economic crisis and the variables that interacts with all the other variables. The specification of Equation 1 is:

\footnotetext{
${ }^{1}$ A cost function approach cannot be used in this study because this approach needs data of price of inputs and outputs and these data are not available.
} 


$$
\begin{aligned}
\ln y_{i t}=\beta_{0}+ & \beta_{L} \ln L_{i t}+\beta_{K} \ln K_{i t}+\beta_{M} \ln M_{i t}+\beta_{E} \ln E_{i t}+\beta_{t} t+0.5 \beta_{L L}\left[\ln L_{i t}\right]^{2} \\
& +0.5 \beta_{K K}\left[\ln K_{i t}\right]^{2}+0.5 \beta_{M M}\left[\ln M_{i t}\right]^{2}+0.5 \beta_{E E}\left[\ln E_{i t}\right]^{2}+0.5 \beta_{t t}[t]^{2} \\
& +\beta_{L K}\left[\ln L_{i t} * \ln K_{i t}\right]+\beta_{L M}\left[\ln L_{i t} * \ln M_{i t}\right]+\beta_{L E}\left[\ln L_{i t} * \ln E_{i t}\right] \\
& +\beta_{K M}\left[\ln K_{i t} * \ln M_{i t}\right]+\beta_{K E}\left[\ln K_{i t} * \ln E_{i t}\right]+\beta_{M E}\left[\ln M_{i t} * \ln E_{i t}\right] \\
& +\beta_{L t}\left[\ln L_{i t} * t\right]+\beta_{K t}\left[\ln K_{i t} * t\right]+\beta_{M t}\left[\ln M_{i t} * t\right]+\beta_{E t}\left[\ln E_{i t} * t\right]+\beta_{D} D \\
& +\beta_{L D}\left[\ln L_{i t} * D\right]+\beta_{K D}\left[\ln K_{i t} * D\right]+\beta_{M D}\left[\ln M_{i t} * D\right]+\beta_{E D}\left[\ln E_{i t} * D\right] \\
& +\beta_{t D}[t * D]+\left\{0.5 \beta_{L L D}\left[\ln L_{i t}\right]^{2} * D\right\}+\left\{0.5 \beta_{K K D}\left[\ln K_{i t}\right]^{2} * D\right\} \\
& +\left\{0.5 \beta_{M M D}\left[\ln M_{i t}\right]^{2} * D\right\}+\left\{0.5 \beta_{E E D}\left[\ln E_{i t}\right]^{2} * D\right\}+\left\{0.5 \beta_{t t D}[t]^{2} * D\right\} \\
& +\beta_{L K D}\left[\ln L_{i t} * \ln K_{i t} * D\right]+\beta_{L M D}\left[\ln L_{i t} * \ln M_{i t} * D\right] \\
& +\beta_{L E D}\left[\ln L_{i t} * \ln E_{i t} * D\right]+\beta_{K M D}\left[\ln K_{i t} * \ln M_{i t} * D\right] \\
& +\beta_{K E D}\left[\ln K_{i t} * \ln E_{i t} * D\right]+\beta_{M E D}\left[\ln M_{i t} * \ln E_{i t} * D\right]+\beta_{L t D}\left[\ln L_{i t} * t * D\right] \\
& +\beta_{K t D}\left[\ln K_{i t} * t * D\right]+\beta_{M t D}\left[\ln M_{i t} * t * D\right]+\beta_{E t D}\left[\ln E_{i t} * t * D\right]+v_{i t} \\
& -u_{i t}
\end{aligned}
$$

where $y$ represents output, $L$ represents labour, $K$ is capital, $M$ is material, $E$ is energy, $t$ is time, $i$ is firm, $D$ is a dummy crisis, $\beta s$ are parameters to be estimated, ln denotes natural logarithm, $v_{i t}$ is the stochastic error term, and $u_{i t}$ is the technical efficiency variable.

The impact of trade reform on technical inefficiency in Equation 2 is specified to include a set of trade reform variables: effective rate of protection $(E R P)$ and import ratio $(I M P)$. These variables are chosen because they are widely used in the literature and the data for these variables are the most consistently available throughout the selected period. ${ }^{2}$ Also included is a set of other variables affecting efficiency: age of firm $(A G E)$, capital intensity $(C I)$, ratio of non-production workers $(N P W)$, foreign ownership (FOREIGN), and a dummy crisis $(D)$. Hence, the inefficiency function is written as:

$$
\begin{array}{rl}
u_{i t}=\delta_{0}+\delta_{1} & E R P_{i t}+\delta_{2} I M P_{i t}+\delta_{3} A G E_{i t}+\delta_{4} C I_{i t}+\delta_{5} N P W_{i t}+\delta_{6} F_{O R E I G N_{i t}} \\
& +\delta_{7}\left(E R P_{i t} * D\right)+\delta_{8}\left(I M P_{i t} * D\right)+\delta_{9}\left(A G E_{i t} * D\right)+\delta_{10}\left(C I_{i t} * D\right) \\
& +\delta_{11}\left(N P W_{i t} * D\right)+\delta_{12}\left(F \text { OREIGN } N_{i t} * D\right)+\delta_{13} D+w_{i t}
\end{array}
$$

where $w$ is an error term.

\section{Data Sources}

The primary data source for this study is the annual Survey of Medium and Large Manufacturing Industries (Survei Tahunan Statistik Industri or SI hereafter) conducted by the

\footnotetext{
${ }^{2}$ Greenaway et al. (2002) provide more detailed discussion regarding alternative measures of liberalization such as import tariffs, export subsidies, coverage of quotas, and black market premia.
} 
Indonesian Central Board of Statistics (Badan Pusat Statistik or hereafter BPS). The survey covers the basic information for each firm, such as specific identification code, industrial classification, and first year of production. This survey also covers ownership information (domestic and foreign ownerships), production information (gross output, value added, number of production, non-production, and family workers, value of capital and investment, raw material, and energy consumption), and other information (share of production exported and value of imported material).

All monetary output and input (capital, material, and energy) are deflated using various indices and expressed in 1993 Indonesian rupiah. The output and material values are deflated using the wholesale price index; the value of capital is deflated using the machinery price index; the nominal value of energy is the summation of electricity and fuel expenditures, which are deflated using the electricity price index and fuel price index, respectively. ${ }^{3}$

To construct the unique balanced panel data covering the selected period (1981-2000) for the chemicals industry, this study makes several adjustments. The 1981-2000 period is selected because it covers before and after trade reform and covers the largest number of observations as well. From the original data set, this study makes two adjustments. The first adjustment is to remove nonsense, noise, and missing values from the data. The second adjustment is made to capital data. Observations that have missing values in the capital data are predicted using Vial (2006) methodology. After the adjustment process and the construction of a balanced panel, the final dataset consist of 4,820 observations of firms in the Indonesian chemicals industry. A detailed explanation about data sources and the adjustment process is given at the beginning of the Appendix A.1.

Among the variables used in Equations 3 and 4 are ERP, IMP, AGE, CI, NPW, FOREIGN, and D. ERP used in this study is ERP as calculated by World Bank (1981) and used by Pangestu and Boediono (1986), Fane and Condon (1996), and Widodo (2008). The first two studies and the last three studies examine the trade regime before and after trade liberalization, respectively. ERP estimates provided by these studies are for 1976, 1987, 1991, 1995, and 2001. To obtain yearly data for ERP, a standard linear interpolation is used. IMP is measured by the proportion of import material to total material used by firms, $A G E$ is measured by the different between the survey year and the year of starting production, $C I$ is measured by the proportion of capital to the total number of workers employed by firms, NPW is measured by

\footnotetext{
${ }^{3}$ The wholesale electricity price index data are not available before 1985 . Therefore, the wholesale price index of electrical machinery, apparatus, appliances and supplies at two-digit ISIC product codes at 1993 constant price is used to deflate the monetary values of electricity inputs.
} 
the proportion of non-production workers to total workers employed by firms, FOREIGN ownership is measured by a dummy variable: 1 if the share of foreign ownership is greater than 0 per cent, and 0 otherwise, and $D$ is a dummy variable for crisis. Definition and construction of variables are presented in the Appendix A.2.

\section{$5 \quad$ Results and Analysis}

\section{Choosing the Functional Form}

Seven null hypotheses are tested to choose an appropriate functional form that represents the data, with detailed results presented in the Appendix A.3. Given the results of the tests, the observations are split into sub-samples for pre-crisis (1981-1996) and post-crisis (1997-2000). By splitting the observations into pre-crisis and post-crisis, the dummy crisis and the variables that interact with the dummy crisis variable in Equation 3 are not required to be included into the equation. Therefore, the estimation of the stochastic frontier in this study uses the translog production frontier as follows:

$$
\begin{aligned}
\ln y_{i t}=\beta_{0}+ & \beta_{L} \ln L_{i t}+\beta_{K} \ln K_{i t}+\beta_{M} \ln M_{i t}+\beta_{E} \ln E_{i t}+\beta_{t} t+0.5 \beta_{L L}\left[\ln L_{i t}\right]^{2} \\
& +0.5 \beta_{K K}\left[\ln K_{i t}\right]^{2}+0.5 \beta_{M M}\left[\ln M_{i t}\right]^{2}+0.5 \beta_{E E}\left[\ln E_{i t}\right]^{2}+0.5 \beta_{t t}[t]^{2} \\
& +\beta_{L K}\left[\ln L_{i t} * \ln K_{i t}\right]+\beta_{L M}\left[\ln L_{i t} * \ln M_{i t}\right]+\beta_{L E}\left[\ln L_{i t} * \ln E_{i t}\right] \\
& +\beta_{K M}\left[\ln K_{i t} * \ln M_{i t}\right]+\beta_{K E}\left[\ln K_{i t} * \ln E_{i t}\right]+\beta_{M E}\left[\ln M_{i t} * \ln E_{i t}\right] \\
& +\beta_{L t}\left[\ln L_{i t} * t\right]+\beta_{K t}\left[\ln K_{i t} * t\right]+\beta_{M t}\left[\ln M_{i t} * t\right]+\beta_{E t}\left[\ln E_{i t} * t\right]+v_{i t} \\
& -u_{i t}
\end{aligned}
$$

where the variables are as previously defined in Equation 3.

The inefficiency function can also be written as follows:

$$
u_{i t}=\delta_{0}+\delta_{1} E R P_{i t}+\delta_{2} I M P_{i t}+\delta_{3} A G E_{i t}+\delta_{4} C I_{i t}+\delta_{5} N P W_{i t}+\delta_{6} \text { FOREIGN }_{i t}+w_{i t} \mathbf{6}
$$

where the variables are as previously defined in Equation 4.

\section{Estimating the Effect of Trade Reform on Technical Efficiency}

Using Equations 5 and 6 above, this section estimates the effect of trade reform on firm-level technical efficiency in the Indonesian chemicals industry. Separate estimation is performed for the pre-crisis and post-crisis periods. Table 2 displays estimation results of the stochastic frontier production function for chemicals industry in Indonesia. In the one-stage approach, the SPF estimates are used to set a technology frontier, but they have limited direct economic implications for output. The impact of each input on output depends on the interactions of the coefficients of all terms involving the input (first and second order). Hence, output elasticity with respect to labour, capital, material, and energy, along with return to scale and technical 
change, have been calculated and are presented separately in Table $3 .{ }^{4}$ The firm specific results are not presented here due to space limitation but they are available upon request.

Table 2: Maximum Likelihood Estimates of the Stochastic Production Frontiers in Chemicals Industry (ISIC 35)

\begin{tabular}{|c|c|c|c|c|}
\hline & \multicolumn{2}{|c|}{ Pre-Crisis (1981-1996) } & \multicolumn{2}{|c|}{ Post-Crisis (1997-2000) } \\
\hline & Coefficient & t-ratio & Coefficient & t-ratio \\
\hline $\begin{array}{l}\text { Production Frontier } \\
\text { (Dependent Variable: } \ln Y \text { ) }\end{array}$ & & & & \\
\hline Constant & 2.228 & $3.013 * * *$ & 5.932 & $5.225^{* * *}$ \\
\hline $\ln L$ & 0.237 & $2.058 * *$ & 0.425 & $1.796^{* *}$ \\
\hline $\ln K$ & -0.270 & $-1.420^{*}$ & -2.023 & $-6.171 * * *$ \\
\hline $\ln M$ & 0.505 & $7.259 * * *$ & 1.531 & $8.712 * * *$ \\
\hline $\ln E$ & 0.418 & $6.074 * * *$ & 0.114 & 0.838 \\
\hline $\mathrm{T}$ & -0.054 & $-3.110 * * *$ & 0.017 & 0.110 \\
\hline$[\mathrm{lnL}]^{2}$ & 0.125 & $6.294 * * *$ & 0.103 & $2.810^{* * *}$ \\
\hline$[\operatorname{lnK}]^{2}$ & 0.315 & $11.519 * * *$ & 0.665 & $10.899 * * *$ \\
\hline$[\ln M]^{2}$ & 0.130 & $20.835 * * *$ & 0.199 & $10.397 * * *$ \\
\hline$[\operatorname{lnE}]^{2}$ & 0.047 & $6.949 * * *$ & 0.003 & 0.244 \\
\hline $\mathrm{T}^{2}$ & -0.005 & $-6.533 * * *$ & 0.077 & $3.015^{* * *}$ \\
\hline $\ln L^{*} \ln K$ & 0.019 & 0.919 & -0.022 & -0.531 \\
\hline $\operatorname{lnL} * \ln M$ & -0.065 & $-6.657 * * *$ & -0.022 & -1.102 \\
\hline $\ln L^{*} \ln E$ & -0.013 & $-1.521 *$ & -0.030 & $-1.889 * *$ \\
\hline $\ln K^{*} \ln M$ & -0.137 & $-12.790 * * *$ & -0.335 & $-10.250 * * *$ \\
\hline $\ln K^{*} \ln E$ & -0.070 & $-5.911 * * *$ & 0.012 & 0.589 \\
\hline $\ln \mathrm{M}^{*} \ln \mathrm{E}$ & 0.000 & 0.180 & -0.004 & $-3.236 * * *$ \\
\hline $\operatorname{lnL} * \mathrm{~T}$ & -0.002 & -1.266 & 0.009 & 0.556 \\
\hline $\operatorname{lnK} K^{*} \mathrm{~T}$ & 0.014 & $4.648 * * *$ & -0.057 & $-1.979 * *$ \\
\hline $\ln M^{*} \mathrm{~T}$ & -0.004 & $-2.773 * * *$ & 0.037 & $2.517 * * *$ \\
\hline $\ln E^{*} \mathrm{~T}$ & -0.002 & $-2.657 * * *$ & -0.009 & -0.857 \\
\hline Log-likelihood & & $-1,547.875$ & & -410.517 \\
\hline No. of Cross-sections & & 16 & & 4 \\
\hline No. of Firms & & 241 & & 241 \\
\hline Observation & & 3,856 & & 964 \\
\hline
\end{tabular}

Source: Author's calculation using the model specified in Equation 5. ***,**,* denote 1\%, 5\% and $10 \%$ level of significance respectively.

The calculated elasticity values in Table 3 show that the average output elasticity with respect to labour is negative for several years, particularly from 1983 to 1996. In contrast, the elasticity for capital and material are positive for all observed years, with average values of 0.71 for the former and 0.52 for the latter. The same is also true for energy, as the average output elasticity is positive at 0.08 . In the Indonesian chemical industry the largest output elasticity is for capital (ranging from 0.48 to 0.79 during the years observed). High output elasticity for capital in the chemical industry is consistent with the capital-intensive character of chemicals production and its heavy reliance on advanced manufacturing technologies (Wacker et al. , 2006).

\footnotetext{
${ }^{4}$ There is a potential bias between the production function and inefficiency function because part of material (M) is imported (IMP). However, the low correlation coefficient between these two variables (-0.004) suggests that for this sample the bias may not be large.
} 
Summing the four elasticity values, the annual average value of RTS in the Indonesian chemicals industry is 1.26 between 1981 and 2000. This result suggests an increasing return to scale for the Indonesian chemical industry. ${ }^{5}$ Comparing the annual average values of RTS before and during the crisis period, as shown in Table 3, the average value before the economic crisis $(1981-1996)$ is 1.27 , whereas the value is 1.23 during the crisis period (1997-2000). Even though the eightfold increase in the real value of output from 1981 to 2000 far exceeds the less than threefold increase in the number of establishments, firms remain too small to achieve full economies of scale.

Table 3: Output Elasticity of Inputs, RTS, and TC for the Indonesian Chemicals Industry (ISIC 35)

\begin{tabular}{|c|c|c|c|c|c|c|}
\hline \multirow[t]{2}{*}{ Year } & \multicolumn{4}{|c|}{ Output Elasticities of Inputs } & \multirow[t]{2}{*}{ RTS } & \multirow[t]{2}{*}{ TC } \\
\hline & Labour & Capital & Material & Energy & & \\
\hline 1981 & & 0.6427 & 0.5331 & 0.0704 & 1.2473 & 0.0096 \\
\hline 1982 & 0.0009 & 6467 & 4942 & 1035 & 1.2453 & 0.0047 \\
\hline 1983 & -0.0161 & 0.5937 & 0.5280 & 0.1151 & 1.2207 & -0.0026 \\
\hline 1984 & -0.0176 & 0.6546 & 0.5231 & 0.0867 & 1.2468 & -0.0057 \\
\hline 1985 & -0.0202 & 0.6483 & 5045 & 0.1099 & 1.2424 & -0.0110 \\
\hline 1986 & -0.0214 & 0.6842 & 0.4997 & 0.0950 & 1.2575 & -0.0152 \\
\hline 1987 & -0.0357 & 0.6842 & 0.5263 & 0.0808 & 1.2556 & -0.0205 \\
\hline 1988 & -0.0447 & 0.6755 & 0.5351 & 0.0845 & 1.2504 & -0.0261 \\
\hline 1989 & -0.0365 & 0.7311 & 0.5084 & 0.0728 & 1.2758 & -0.0295 \\
\hline 1990 & -0.0333 & 0.7543 & 0.5014 & 0.0655 & 1.2879 & -0.0342 \\
\hline 1991 & -0.0391 & & & .0632 & 1.2928 & -0.0389 \\
\hline 1992 & -0.0446 & 0.7451 & 0.4766 & 0.1014 & 1.2784 & -0.0449 \\
\hline 1993 & -0.0405 & 0.7661 & 0.4845 & 0.0815 & 1.2916 & -0.0500 \\
\hline 1994 & -0.0550 & 0.7481 & 0.4905 & 0.0958 & 1.2794 & -0.0557 \\
\hline 1995 & -0.0652 & 0.7851 & 0.5027 & 0.0709 & 1.2934 & -0.0595 \\
\hline 1996 & -0.0774 & & 0.5110 & 0.0893 & 1.2757 & -0.0661 \\
\hline 1997 & 0.0007 & 0.6683 & 0.5285 & 0.0599 & 1.2574 & -0.0668 \\
\hline 1998 & 0.0150 & 0.6149 & 0.5661 & 0.0513 & 1.2473 & 0.0139 \\
\hline 1999 & 0.0008 & 0.6284 & 0.5617 & 0.0444 & 1.2353 & 0.0746 \\
\hline 2000 & 0.0416 & 0.4754 & 0.6474 & 0.0296 & 1.1939 & 0.1694 \\
\hline 1981-1996 & -0.0341 & & 0.5074 & 0.0866 & 1.2651 & -0.0279 \\
\hline $1997-2000$ & 0.0145 & 0.5967 & 0.5759 & 0.0463 & 1.2335 & 0.0478 \\
\hline Total & -0.0244 & 0.6835 & 0.5211 & 0.0786 & 1.2588 & -0.0127 \\
\hline
\end{tabular}

Source: Authors' calculation using the model specified in Equation 5 and the coefficient estimates fromError!

Reference source not found..

\footnotetext{
${ }^{5}$ With increasing returns to scale, average cost of production is above marginal cost. For firms to be viable their prices must be greater than marginal cost, implying imperfect competition among domestic producers. Imperfect competition is a common outcome in developing countries when domestic producers are protected from import competition.
} 
Table 3 shows that the annual average rate of technical change in the Indonesian chemicals industry is $-1.27 \%$ and the rate of technical change in the Indonesian chemicals industry ranges from $-6.68 \%$ to $16.94 \%$. The rate of technical change is negative in 1983 and more negative until 1997. From 1998 to 2000, however, the rate of technical change becomes positive. The positive rate of technical change is due to a negative coefficient of time and a positive coefficient of time square in the post-crisis estimated production function, which is fitted to only four years of data. Looking at different sub-periods, the average rate of technical change is $-2.79 \%$ during the pre-crisis period and $4.78 \%$ during the post-crisis period.

Moving to the estimates of inefficiency function, Table 4 shows the results of estimation in the Indonesian chemicals industry. The estimated coefficients of ERP are positive and statistically significant at the $1 \%$ level in both the pre-crisis and post-crisis period, suggesting that the decrease in ERP contributes to decreasing technical inefficiency (or increasing technical efficiency). These results are consistent with the premise that trade reform increases technical efficiency.

Table 4: Estimates of Technical Inefficiency Parameters in Chemicals Industry (ISIC 35)

\begin{tabular}{|l|r|r|r|r|}
\hline & \multicolumn{2}{|l|}{ Pre-Crisis (1981-1996) } & \multicolumn{2}{l|}{ Post-Crisis (1997-2000) } \\
\hline & \multicolumn{1}{|l|}{ Coefficient } & \multicolumn{1}{l|}{ t-ratio } & \multicolumn{1}{c|}{ Coefficient } & \multicolumn{1}{c|}{ t-ratio } \\
\hline Inefficiency Function & & & & \\
(Dependent Variable: $u$ ) & & & & \\
Constant & -0.052 & $-2.529 * * *$ & -5.078 & $-9.216^{* * *}$ \\
ERP & $\mathbf{0 . 0 0 3}$ & $\mathbf{1 3 . 7 4 4} * * *$ & $\mathbf{0 . 0 7 3}$ & $\mathbf{5 . 1 1 0 * * *}$ \\
Import Ratio & $\mathbf{- 0 . 0 0 1}$ & $\mathbf{- 4 . 6 5 9 * * *}$ & $\mathbf{- 0 . 0 2 1}$ & $\mathbf{- 1 5 . 4 5 5 * * *}$ \\
AGE & 0.000 & 0.467 & 0.013 & $3.486^{* * *}$ \\
Capital Intensity & 0.002 & $14.527^{* * *}$ & 0.009 & $10.930^{* * *}$ \\
Non-Production Workers & -0.005 & $-22.451^{* * *}$ & -0.008 & $-3.732^{* * *}$ \\
Foreign Ownership & -0.140 & $-22.906^{* * *}$ & -2.032 & $-10.781^{* * *}$ \\
Sigma-squared & 0.131 & $34.119^{* * *}$ & 0.938 & $8.263^{* * *}$ \\
Gamma & 0.00008 & $17.696^{* * *}$ & 0.908 & $75.904 * * *$ \\
\hline No. of Cross-sections & & 16 & & 4 \\
No. of Firms & & 241 & & 241 \\
Observation & & 3,856 & & 964 \\
\hline
\end{tabular}

Source: Authors' calculation using the model specified in Equation 6. The t-statistics are in parenthesis. $* * *, * *$ and $*$ denote $1 \%, 5 \%$ and $10 \%$ level of significance respectively.

The second variable representing trade reform in this model is IMP. The results show that the estimated coefficients of IMP are negative and statistically significant at the $1 \%$ level, both before and after the economic crisis, which indicates that IMP has negative effects on technical inefficiency (or positive effect on technical efficiency). These results support the premise that trade reform leads to decreased technical inefficiency (or increased technical efficiency).

With regard to variables not associated with trade reform variables, the coefficient of AGE in the pre-crisis period is zero and not statistically significant. In the post-crisis period, AGE has 
positive effects on technical inefficiency and is statistically significant at the $1 \%$ level. This result indicates that in the chemicals industry older firms have higher technical inefficiency than young ones. The positive effect of age on technical inefficiency is in line with the findings of Pitt and Lee (1981), and Suyanto (2010), whereas the insignificant effect of age on technical inefficiency is in line with the findings of Margono and Sharma (2006)

The coefficients of capital intensity before and after the economic crisis are positive and statistically significant at the $1 \%$ level, suggesting that a higher ratio of capital intensity leads to increasing technical inefficiency (or decreasing technical efficiency). The positive impact of capital intensity on technical inefficiency is also found by Islam (1978). The coefficients of the ratio of non-production workers are negative and statistically significant at $1 \%$ level in both before and after the economic crisis, thus suggesting that a higher ratio of non-production workers reduces technical inefficiency.

The estimated coefficients of foreign ownership are negative and statistically significant at $1 \%$ level in both the pre-crisis and post-crisis period, suggesting that foreign-owned firms are, on average, less inefficient than domestic firms. This finding is consistent with the premise that foreign firms generally have more experience in serving markets and have more up to date knowledge, which enables them to be more efficient than domestically owned firms. These negative effects of ownership status on technical inefficiency confirm findings of Pitt and Lee (1981), Suyanto (2010) and Suyanto et al. (2012).

\section{Conclusions and Policy Implications}

This study examines the effects of trade reform on technical efficiency in the Indonesian chemicals industry by using firm-level data covering the period 1981-2000. This paper uses the one-stage stochastic production frontier model developed by Battese and Coelli (1995). Seven null hypotheses are tested to find the appropriate estimation approach for the dataset. The results suggest that the translog production frontier with non-neutral technological change and technical inefficiency appears to be the appropriate specification for the firms in the Indonesian chemicals industry. Further, the results support splitting observations into the precrisis (1981-1996) and the post-crisis (1997-2000) to improve the statistical fit compared to imposing the same coefficient estimates in both sub-periods.

Two variables represent trade reform in this empirical study: the effective rate of protection (ERP) and the ratio of imported materials to total use of materials (IMP). Higher ERP indicates higher protection while higher IMP suggests low trade barriers that lead to greater reliance on imported inputs. The empirical findings suggest ERP has positive effects on technical 
inefficiency, meaning that an increase in ERP increases inefficiency (or decreases technical efficiency), in both pre-crisis and post-crisis periods. The results further show that IMP has negative effects on technical inefficiency, meaning that an increase in IMP decreases technical inefficiency (or increases technical efficiency), in both pre-crisis and post-crisis periods. Thus, both these results support the premise that trade reform increases technical efficiency.

These findings support the continuing liberalization of trade policies provided by the Indonesian government, particularly for the Indonesian chemicals industry. Based on the findings further efficiency gains should be forthcoming from continued lowering of ERP and removing remaining import barriers that limit the ability for chemicals firms to use imported material in the production process.

Acknowledgement: This paper is based on first author's $\mathrm{PhD}$ dissertation submitted to Curtin University in 2016. She acknowledges her gratitude to the Directorate General of Higher Education (DIKTI), Indonesia for providing her scholarship during her study at Curtin University. The anonymous reviewer's comments and suggestions are also gratefully acknowledged. However, usual disclaimer applies for any error or omission. 


\section{References}

Alam, I. M. S. and A. R. Morrison (2000). "Trade Reform Dynamics and Technical Efficiency: The Peruvian Experience." The World Bank Economic Review 14(2): 309-330.

Amiti, M. and J. Konings (2007). "Trade Liberalization, Intermediate Inputs, and Productivity: Evidence from Indonesia." American Economic Review 97(5): 1611-1638.

Aswicahyono, H., H. Hill and D. Narjoko (2010). "Industrialisation after a Deep Economic Crisis: Indonesia." Journal of Development Studies 46(6): 1084-1108.

Bartelsman, E. J. and M. Doms (2000). "Understanding Productivity: Lessons from Longitudinal Microdata." Journal of Economic Literature 38(3): 569-594.

Basri, M. C. (2002) Why Trends of Protection Changed Over Time in Indonesia? Institute of Southeast Asian Studies, Code: VRS2/2, Singapore

Battese, G. E. and T. J. Coelli (1995). "A Model for Technical Inefficiency Effects in a Stochastic Frontier Production Function for Panel Data." Empirical Economics 20(2): 325-332.

Coelli, T., D. S. P. Rao and G. E. Battese (2005). An Introduction to Efficiency and Productivity Analysis. New York, Springer.

Corden, W. M. (1974). Trade Policy and Economic Welfare. Oxford, Clarendon Press.

Dhanani, S. (2000). Indonesia: Strategy for Manufacturing Competitiveness Jakarta, United Nations Industrial Development Organization (UNIDO)

Driffield, N. L. and U. S. Kambhampati (2003). "Trade Liberalization and the Efficiency of Firms in Indian Manufacturing." Review of Development Economics 7(3): 419-430.

Fane, G. and T. Condon (1996). "Trade Reform in Indonesia, 1987-95." Bulletin of Indonesian Economic Studies 32(3): 33-54.

Gökçekuş, Ö. (1995). "The Effects of Trade Exposure on Technical Efficiency: New Evidence from the Turkish Rubber Industry." Journal of Productivity Analysis 6(1): 77-85.

Greenaway, D., Morgan, W. and Wright, P. (2002) Trade liberalization and growth in developing countries, Journal of Development Economics, 67:229-44.

Grossman, G. M. and E. Helpman (1991). "Trade, Knowledge Spillovers, and Growth." European Economic Review 35(2-3): 517-526.

Handoussa, H., M. Nishimizu and J. M. Page Jr (1986). "Productivity Change in Egyptian Public Sector Industries after 'The Opening', 1973-1979." Journal of Development Economics 20(1): 53-73.

Hill, H. and K. P. Kalirajan (1993). "Small Enterprise and Firm-level Technical Efficiency in the Indonesian Garment Industry." Applied Economics 25(9): 1137.

Ikhsan, M. (2007). "Total Factor Productivity Growth in Indonesian Manufacturing: A Stochastic Frontier Approach." Global Economic Review 36(4): 321-342.

Islam, R. (1978). "Reasons for Idle Capital: The Case of Bangladesh Manufacturing." Bangladesh Development Studies 6(1): 27-54.

Kalirajan, K P. and Salim, R. (1997) Economic Reforms and Capacity Realization in Bangladesh: An Empirical Analysis, Journal of Industrial Economics; 45: 387-403.

Kodde, D. A. and F. C. Palm (1986). "Notes and Comments: Wald Criteria for Jointly Testing Equality and Inequality Restrictions." Econometrica 54(5): 1243.

Krugman, P. (1987). "The Narrow Moving Band, the Dutch Disease, and the Competitive Consequences of Mrs. Thatcher: Notes on Trade in the Presence of Dynamic Scale Economies." Journal of Development Economics 27(1-2): 41-55.

Loecker, J. D. and P. K. Goldberg (2013) "Firm Performance in a Global Market." NBER Working Paper Series.

Lucas, R. E., Jr. (1988). "On the Mechanics of Economic Development." Journal of Monetary Economics 22(1): 3-42. 
Margono, H. and S. C. Sharma (2006). "Efficiency and Productivity Analyses of Indonesian Manufacturing Industries." Journal of Asian Economics 17(6): 979-995.

Nishimizu, M. and J. M. Page, Jr. (1982). "Total Factor Productivity Growth, Technological Progress and Technical Efficiency Change: Dimensions of Productivity Change in Yugoslavia, 1965-78." Economic Journal 92(368): 920-936.

Pack, H. (1988). Industrialization and Trade. Handbook of Development Economics. H. B. Chenery and T. N. Srinivasan. Amsterdam, North Holland, Elsevier Science Publishers B. V. 1: 335-380.

Pangestu, M. and Boediono (1986). Indonesia: The Structure and Causes of Manufacturing Sector Protection. The Political Economy of Manufacturing Protection: Experiences of ASEAN and Australia. C. Findlay and R. Garnaut. New South Wales, Australia, Allen \& Unwin Australia Pty Ltd: 1-47.

Parameswaran, M. (2002) "Economic Reforms and Technical Efficiency: Firm Level Evidence from Selected Industries in India." Working Paper No: 339, Jawaharlal Nehru University, New Delhi, India.

Pitt, M. M. and L.-F. Lee (1981). "The Measurement and Sources of Technical Inefficiency in the Indonesian Weaving Industry." Journal of Development Economics 9(1): 43-64.

Rodrik, D. (1992a). "The Limits of Trade Policy Reform in Developing Countries." Journal of Economic Perspectives 6(1): 87-105.

Rodrik, D. (1992b) "The Rush to Free Trade in the Developing World: Why So Late? Why Now? Will It Last?" NBER Working Paper Series 3947.

Romer, P. M. (1986). "Increasing Returns and Long-Run Growth." Journal of Political Economy 94(5): 1002-1037.

Salim, R. (1999) Capacity Realization and Productivity Growth in a Developing Country: Has Economic Reform had Impact? Ashgate Publishing Company, U. K.

Salim, R. (2003), Economic Liberalization and Productivity Growth: Further Evidence from Bangladesh, Oxford Development Studies; 31: 85-98.

Sheikh, S. A. and S. Ahmed (2011). "Impact of Trade Liberalization and Domestic Economic Reforms on Technical Efficiency of Agro-Based Industries in Pakistan." International Journal of Business and Social Science 2(23): 219-226.

Suyanto (2010). Foreign Direct Investment, Spillover Effects, and Productivity Growth in Indonesian Manufacturing Industries. Ph.D Thesis Curtin University of Technology.

Suyanto, H. Bloch and R. A. Salim (2012). "Foreign Direct Investment Spillovers and Productivity Growth in Indonesian Garment and Electronics Manufacturing." Journal of Development Studies 48(10): 1397-1411.

Suyanto, R. A. Salim and H. Bloch (2009). "Does Foreign Direct Investment Lead to Productivity Spillovers? Firm Level Evidence from Indonesia." World Development 37(12): 1861-1876.

Tybout, J., J. de Melo and V. Corbo (1991). "The Effects of Trade Reforms on Scale and Technical Efficiency: New Evidence from Chile." Journal of International Economics 31(3-4): 231-250.

Vial, V. (2006). "New Estimates of Total Factor Productivity Growth in Indonesian Manufacturing." Bulletin of Indonesian Economic Studies 42(3): 357-369.

Wacker, J. G., C.-L. Yang and C. Sheu (2006). "Productivity of Production Labor, Nonproduction Labor, and Capital: An International Study." International Journal of Production Economics 103(2): 863-872.

Widodo, T. (2008). "The Structure of Protection in Indonesian Manufacturing Sector." ASEAN Economic Bulletin 25(2): 161-178.

World Bank (1981). Indonesia: Selected Issues of Industrial Development and Trade Strategy. Annex 2 The Foreign Trade Regime. Washington, DC. 


\section{APPENDIX A}

\section{A.1. Sources of data and construction of data set}

The main data source in this study is the Annual Survey of Medium and Large Manufacturing Firms (Survei Tahunan Statistik Industri Perusahaan Menengah dan Besar or SI) conducted by the Indonesian Central Board of Statistics (Badan Pusat Statistik or BPS). The survey is conducted yearly and covers the basic information of each Indonesian manufacturing firm with at least 20 employees, such as industrial classification, firm specific identification code, and first year of production. It also covers ownership information (domestic, foreign, and government), location (sub-district, province), production information (gross output, energy consumption, material, number of workers, and value of fixed capital and investment), and other information (such as income, non-production expenditures, share of production exported, and value of imported material). The numbers of firms varies depending on the year, with the minimum number of 668 manufacturing firms in 1975 to the maximum number of 3,098 firms in 2006. The summary form of the survey, Statistik Industri (SI), is released annually, while firm-level data are available in electronic form and can be obtained under license from BPS.

The annual manufacturing surveys have been conducted since 1975, and the recent data available are for the year 2011; however, this study uses only the data from 1981 to 2000 . The time period is chosen to capture the largest number of firms that appear consistently before and after trade liberalization period.

A consistent balanced panel dataset is constructed by following several steps of adjustment as follow:

Step 1: Adjustment for the variable definitions

In some years, BPS changes the name of the variables. Questionnaires for each year are compared to ensure that variables collected are correct and consistent. If the definitions are not consistent, variables are recalculated to obtain consistent definitions throughout the selected period.

Step 2: Cleaning for noise

The following steps are taken in this study to minimise noise:

a. Firms that have zero or negative value of output, labour, material, or energy are removed.

b. Obvious typing mistakes (or typographical errors) in the raw data are adjusted for consistency. One example is the sharp changes in foreign share, where the foreign 
share in all years is 100 per cent but 0 for certain years. Corrections are made by adjusting 0 percent to 100 percent.

Step 3: Back-casting the missing values for capital

Many establishments report zero or missing values of capital. To fill these gaps, the capital is regressed against the lagged value of real output to obtain predictions for capital at firm level. The replacement value of fixed capital is used as the proxy for capital. This thesis follows the methodology introduced by Vial (2006).

Step 4: Matching firms to construct a balanced panel dataset

A balanced panel data set is obtained by matching firms based on the specific identification code (PSID) using STATA13 software. The BPS classifies firm-level data in SI up to five-digit industrial codes based on the International Standard Industrial Classification (ISIC) with some modification that follows the conditions of Indonesian manufacturing. During the observation period, BPS changed the classification twice in order to accommodate the growing number of manufacturing firms and to follow the changes in ISIC. The reclassification took place in 1990 and 1998. A consistent classification code is obtained by adjusting the industrial codes to the code of 1990 (ISIC revision 2).

Step 5: All monetary output and input (capital, material, and energy) are deflated using various indices and expressed in 1993 Indonesian rupiah. The output and material values are deflated using the wholesale price index; the value of capital is deflated using the machinery price index; the nominal value of energy is the summation of electricity and fuel expenditures, which are deflated using the electricity price index and fuel price index, respectively. 


\section{A.2. Definition of variables}

\begin{tabular}{|c|c|}
\hline Variables & Definition \\
\hline Production Function & \\
\hline & $\begin{array}{l}\text { Output (in million rupiah), which is deflated using a WPI at } 1993 \text { constant } \\
\text { prices }\end{array}$ \\
\hline $\mathrm{L}$ & $\begin{array}{l}\text { Labour (number of workers) is the total number of employees directly and } \\
\text { indirectly engaged in productions }\end{array}$ \\
\hline K & $\begin{array}{l}\text { Capital (billion rupiah), which is deflated using a WPI for machinery at } \\
1993 \text { constant prices }\end{array}$ \\
\hline M & $\begin{array}{l}\text { Material (million rupiah), which is deflated using a WPI at } 1993 \text { constant } \\
\text { prices }\end{array}$ \\
\hline $\mathrm{E}$ & $\begin{array}{l}\text { Energy (million rupiah) is the sum of electricity and fuel expenditures, } \\
\text { which are deflated using a WPI for electricity and fuel price index at } 1993 \\
\text { constant prices }\end{array}$ \\
\hline Inefficiency Function & \\
\hline ERP & $\begin{array}{l}\text { ERP is calculated by World Bank (1981), Pangestu and Boediono (1986), } \\
\text { Fane and Condon (1996), and Widodo (2008). }\end{array}$ \\
\hline IMP & $\begin{array}{l}\text { The import ratio is measured by the proportion of import material to total } \\
\text { material used by firms. }\end{array}$ \\
\hline AGE & $\begin{array}{l}\text { The age of firms is measured by the difference between the survey year } \\
\text { and the year of starting production. }\end{array}$ \\
\hline $\mathrm{CI}$ & $\begin{array}{l}\text { The capital intensity ratio is measured by the proportion of capital to the } \\
\text { total number of workers employed by firms. }\end{array}$ \\
\hline NPW & $\begin{array}{l}\text { The ratio of non-production workers is measured by the proportion of non- } \\
\text { production workers to total workers employed by firms. }\end{array}$ \\
\hline FOREIGN & $\begin{array}{l}\text { Foreign ownership is measured by a dummy variable: } 1 \text { if the share of } \\
\text { foreign ownership is greater than } 0 \text { per cent, and } 0 \text { otherwise. }\end{array}$ \\
\hline $\mathrm{D}$ & $\begin{array}{l}\text { Economic crisis is measured by a dummy variable: } 1 \text { if the year of } \\
\text { observation is } 1997 \text { onwards, and } 0 \text { if the year of observation is before } \\
1997 \text {. }\end{array}$ \\
\hline
\end{tabular}

\section{A.3. Choosing the Functional Form}

The first step in the SFA is to find an appropriate functional form that represents the data. Given the specification of the translog model in Equation 3, various sub-models of the translog are considered and tested under a number of null hypotheses. The first null hypotheses is to test whether the dummy crisis coefficients are equal to zero for both the inefficiency and production functions, the restriction is $\delta_{7}=\delta_{8}=\delta_{9}=\delta_{10}=\delta_{11}=\delta_{12}=\delta_{13}=\beta_{D}=\beta_{L D}=\beta_{K D}=\beta_{M D}=$ $\beta_{E D}=\beta_{t D}=\beta_{L L D}=\beta_{K K D}=\beta_{M M D}=\beta_{E E D}=\beta_{t t D}=\beta_{L K D}=\beta_{L M D}=\beta_{L E D}=\beta_{K M D}=\beta_{K E D}=\beta_{M E D}=$ $\beta_{L t D}=\beta_{K t D}=\beta_{M t D}=\beta_{E t D}=0$. To test no effect only for the inefficiency function, the restriction is $\delta_{7}=$ $\delta_{8}=\delta_{9}=\delta_{10}=\delta_{11}=\delta_{12}=\delta_{13}=0$. Finally, to test no effect only for the production function, the restriction is $\beta_{D}=\beta_{L D}=\beta_{K D}=\beta_{M D}=\beta_{E D}=\beta_{t D}=\beta_{L L D}=\beta_{K K D}=\beta_{M M D}=\beta_{E E D}=\beta_{t t D}=\beta_{L K D}=\beta_{L M D}=\beta_{L E D}=$ $\beta_{K M D}=\beta_{K E D}=\beta_{M E D}=\beta_{L t D}=\beta_{K t D}=\beta_{M t D}=\beta_{E t D}=0$.

A null hypothesis of the second order parameters equal zero (i.e., $\beta_{L L}=\beta_{K K}=\beta_{M M}=\beta_{E E}=$ $\beta_{t t}=\beta_{L K}=\beta_{L M}=\beta_{L E}=\beta_{K M}=\beta_{K E}=\beta_{M E}=\beta_{L L D}=\beta_{K K D}=\beta_{M M D}=\beta_{E E D}=\beta_{t t D}=\beta_{L K D}=\beta_{L M D}=$ $\left.\beta_{L E D}=\beta_{K M D}=\beta_{K E D}=\beta_{M E D}=0\right)$ is to test whether the Cobb-Douglas frontier is appropriate 
for the data set. A null hypothesis of the interacting parameters of input and time equal zero (i.e., $\beta_{L t}=\beta_{K t}=\beta_{M t}=\beta_{E t}=\beta_{L t D}=\beta_{K t D}=\beta_{M t D}=\beta_{E t D}=0$ ) is to test for Hicks-neutral technological progress. Similarly, a null hypothesis of the time parameters equal zero (i.e., $\beta_{t}$ $\left.=\beta_{t t}=\beta_{L t}=\beta_{K t}=\beta_{M t}=\beta_{E t}=\beta_{t D}=\beta_{t t D}=\beta_{L t D}=\beta_{K t D}=\beta_{M t D}=\beta_{E t D}=0\right)$ is for no technology progress in the frontier, and a null hypothesis of the parameters of inefficiency function equal zero (i.e., $\delta_{0}=\delta_{1}=\ldots=\delta_{13}=0$ ) is for no-inefficiency.

To test the relevant null hypotheses, a generalized likelihood ratio statistic is employed. This ratio statistic is written as follows:

$$
\lambda=-2\left[l\left(H_{0}\right)-l\left(H_{1}\right)\right]
$$

where $l\left(H_{0}\right)$ is the log-likelihood value of the restricted frontier model, and $l\left(H_{1}\right)$ is the loglikelihood value of the model defined in Equation 3. If the null hypothesis is true, the test statistic has approximately a chi-square distribution with degrees of freedom equal to the number of parameters involved in the restrictions. The test statistic under the null hypothesis of no inefficiency effects has approximately a mixed chi-square distribution, and the critical value for this test is taken from Table 1 of Kodde and Palm (1986). 
Table A.1 Log-likelihood Tests for Model Specification of the Stochastic Production Frontier

\begin{tabular}{|c|c|c|c|c|}
\hline Test & $H_{0}$ & $\lambda$ & $\chi^{2} 1 \%$ & Conclusion \\
\hline $\begin{array}{l}\text { No-effect of } \\
\text { crisis dummies } \\
\text { for inefficiency } \\
\text { and production } \\
\text { function }\end{array}$ & $\begin{array}{l}\delta_{7}=\delta_{8}=\delta_{9}=\delta_{10}=\delta_{11}=\delta_{12}= \\
\delta_{13}=\beta_{D}=\beta_{L D}=\beta_{K D}=\beta_{M D}= \\
\beta_{E D}=\beta_{t D}=\beta_{L L D}=\beta_{K K D}= \\
\beta_{M M D}=\beta_{E E D}=\beta_{t t D}=\beta_{L K D}= \\
\beta_{L M D}=\beta_{L E D}=\beta_{K M D}= \\
\beta_{K E D}=\beta_{M E D}= \\
\beta_{L t D}=\beta_{K t D}=\beta_{M t D}=\beta_{E t D}=0\end{array}$ & 127.25 & 48.27 & $\begin{array}{l}\text { No-effect of } \\
\text { crisis dummies } \\
\text { for inefficiency } \\
\text { and production } \\
\text { function } \\
\text { rejected }\end{array}$ \\
\hline $\begin{array}{l}\text { No-effect of } \\
\text { crisis dummies } \\
\text { for inefficiency }\end{array}$ & $\begin{array}{l}\delta_{7}=\delta_{8}=\delta_{9}=\delta_{10}=\delta_{11}=\delta_{12}= \\
\delta_{13}=0\end{array}$ & 48.79 & 18.48 & $\begin{array}{l}\text { No-effect of } \\
\text { crisis dummies } \\
\text { for inefficiency } \\
\text { rejected }\end{array}$ \\
\hline $\begin{array}{l}\text { No-effect of } \\
\text { crisis dummies } \\
\text { for production } \\
\text { function }\end{array}$ & $\begin{array}{l}\beta_{D}=\beta_{L D}=\beta_{K D}=\beta_{M D}= \\
\beta_{E D}=\beta_{t D}=\beta_{L L D}=\beta_{K K D}= \\
\beta_{M M D}=\beta_{E E D}=\beta_{t t D}=\beta_{L K D}= \\
\beta_{L M D}=\beta_{L E D}=\beta_{K M D}= \\
\beta_{K E D}=\beta_{M E D}= \\
\beta_{L t D}=\beta_{K t D}=\beta_{M t D}=\beta_{E t D}=0\end{array}$ & 53.73 & 38.93 & $\begin{array}{l}\text { No-effect of } \\
\text { crisis dummies } \\
\text { for production } \\
\text { function } \\
\text { rejected }\end{array}$ \\
\hline Cobb-Douglas & $\begin{array}{l}\beta_{L L}=\beta_{K K}=\beta_{M M}=\beta_{E E}= \\
\beta_{t t}=\beta_{L K}=\beta_{L M}=\beta_{L E}= \\
\beta_{K M}=\beta_{K E}=\beta_{M E}=\beta_{L L D}= \\
\beta_{K K D}=\beta_{M M D}=\beta_{E E D}=\beta_{t t D}= \\
\beta_{L K D}=\beta_{L M D}=\beta_{L E D}=\beta_{K M D}= \\
\beta_{K E D}=\beta_{M E D}=0\end{array}$ & 1069.67 & 40.29 & $\begin{array}{l}\text { Cobb-Douglas } \\
\text { rejected }\end{array}$ \\
\hline Hicks Neutral & $\begin{array}{l}\beta_{L t}=\beta_{K t} \quad=\beta_{M t}=\beta_{E t}= \\
\beta_{L t D}=\beta_{K t D}=\beta_{M t D}= \\
\beta_{E t D}=0\end{array}$ & 26.38 & 20.09 & $\begin{array}{l}\text { Hicks Neutral } \\
\text { rejected }\end{array}$ \\
\hline $\begin{array}{l}\text { No- } \\
\text { technological } \\
\text { progress }\end{array}$ & $\begin{array}{l}\beta_{t}=\beta_{t t}=\beta_{L t}=\beta_{K t} \\
=\beta_{M t}=\beta_{E t}=\beta_{t D}=\quad \beta_{t t D}= \\
\beta_{L t D}=\beta_{K t D}=\beta_{M t D}= \\
\beta_{E t D}=0\end{array}$ & 77.25 & 26.22 & $\begin{array}{l}\text { No- } \\
\text { technological } \\
\text { progress } \\
\text { rejected }\end{array}$ \\
\hline No-inefficiency & (i.e. $\left.\delta_{0}=\delta_{1}=\ldots=\delta_{13}=0\right)$ & 487.42 & 27.02 & $\begin{array}{l}\text { No-inefficiency } \\
\text { rejected }\end{array}$ \\
\hline
\end{tabular}

The results of the null hypotheses tests are presented in Table A.1. The first result shows that the hypothesis that each of the dummy variable coefficients in both the production function and the inefficiency function is equal to zero is rejected. The result of the log-likelihood test shows a strong rejection of the null hypothesis at the $1 \%$ level of significance in the Indonesian chemicals industry, suggesting that a model that does not include the effect of economic crisis is an inappropriate specification. 
The second and third fourth hypotheses are to test whether the coefficients of each dummy crisis variable, including interaction variables, is equal to zero for inefficiency and production function, respectively. The restrictions for inefficiency function are $\delta_{7}=\delta_{8}=\delta_{9}=\delta_{10}=\delta_{11}=\delta_{12}=$ $\delta_{13}=0$ and the restrictions for the production function are $\beta_{D}=\beta_{L D}=\beta_{K D}=\beta_{M D}=\beta_{E D}=\beta_{t D}=$ $\beta_{L L D}=\beta_{K K D}=\beta_{M M D}=\beta_{E E D}=\beta_{t t D}=\beta_{L K D}=\beta_{L M D}=\beta_{L E D}=\beta_{K M D}=\beta_{K E D}=\beta_{M E D}=$ $\beta_{L t D}=\beta_{K t D}=\beta_{M t D}=\beta_{E t D}=0$, respectively. The results suggest that both null hypotheses are rejected at the $1 \%$ level of significance.

The fourth null hypothesis is a test to confirm whether the log-linear production frontier (also known as the generalised Cobb-Douglas production function) is appropriate specification for the data under a restriction: $\beta_{L L}=\beta_{K K}=\beta_{M M}=\beta_{E E}=\beta_{t t}=\beta_{L K}=\beta_{L M}=\beta_{L E}=\beta_{K M}=\beta_{K E}=$ $\beta_{M E}=\beta_{L L D}=\beta_{K K D}=\beta_{M M D}=\beta_{E E D}=\beta_{t t D}=\beta_{L K D}=\beta_{L M D}=\beta_{L E D}=\beta_{K M D}=\beta_{K E D}=\beta_{M E D}=0$. Here, the null hypothesis is also rejected at the $1 \%$ level of significance in the Indonesian chemicals industry, suggesting that the generalised Cobb-Douglas model is not an appropriate specification, as compared to the translog model.

The next test is the test for Hicks-neutral technical progress (TP) under a restriction: $\beta_{L t}=\beta_{K t}$ $=\beta_{M t}=\beta_{E t}=\beta_{L t D}=\beta_{K t D}=\beta_{M t D}=\beta_{E t D}=0$. For this test, the null hypothesis is rejected at the $1 \%$ level of significance. The test for a null hypothesis of no-technological progress involves imposing the restriction: $\beta_{t}=\beta_{t t}=\beta_{L t}=\beta_{K t}=\beta_{M t}=\beta_{E t}=\beta_{t D}=\beta_{t t D}=\beta_{L t D}=$ $\beta_{K t D}=\beta_{M t D}=\beta_{E t D}=0$. The statistical results suggest that the no-TP specification is inappropriate, compared to the translog specification with technical progress. The final null hypothesis is for no inefficiency effect, which imposes the restriction: $\delta_{0}=\delta_{1}=\ldots=\delta_{13}=0$. This test also shows a rejection of null hypothesis at $1 \%$ level of significance in the Indonesian chemicals industry.

Given these results, one can conclude that it is required to split the observations into pre-crisis (1981-1996) and post-crisis (1997-2000). By splitting the observations into pre-crisis and postcrisis, the dummy crisis and the variables that interact with the dummy crisis variable are not required to be included into the equation. Therefore, the estimation of the stochastic frontier in this study uses the translog production frontier as follows: 


$$
\begin{aligned}
\ln y_{i t}=\beta_{0}+ & \beta_{L} \ln L_{i t}+\beta_{K} \ln K_{i t}+\beta_{M} \ln M_{i t}+\beta_{E} \ln E_{i t}+\beta_{t} t+0.5 \beta_{L L}\left[\ln L_{i t}\right]^{2} \\
& +0.5 \beta_{K K}\left[\ln K_{i t}\right]^{2}+0.5 \beta_{M M}\left[\ln M_{i t}\right]^{2}+0.5 \beta_{E E}\left[\ln E_{i t}\right]^{2}+0.5 \beta_{t t}[t]^{2} \\
& +\beta_{L K}\left[\ln L_{i t} * \ln K_{i t}\right]+\beta_{L M}\left[\ln L_{i t} * \ln M_{i t}\right]+\beta_{L E}\left[\ln L_{i t} * \ln E_{i t}\right] \\
& +\beta_{K M}\left[\ln K_{i t} * \ln M_{i t}\right]+\beta_{K E}\left[\ln K_{i t} * \ln E_{i t}\right]+\beta_{M E}\left[\ln M_{i t} * \ln E_{i t}\right] \\
& +\beta_{L t}\left[\ln L_{i t} * t\right]+\beta_{K t}\left[\ln K_{i t} * t\right]+\beta_{M t}\left[\ln M_{i t} * t\right]+\beta_{E t}\left[\ln E_{i t} * t\right]+v_{i t} \\
& -u_{i t}
\end{aligned}
$$

where the variables are as previously defined in Equation 3.

The inefficiency function can also be written as follows:

$$
u_{i t}=\delta_{0}+\delta_{1} E R P_{i t}+\delta_{2} I M P_{i t}+\delta_{3} A G E_{i t}+\delta_{4} C I_{i t}+\delta_{5} N P W_{i t}+\delta_{6} F_{O R E I G N}+w_{i t} \mathrm{~A} .3
$$

where the variables are as previously defined in Equation 4. 